\title{
Environmental management policy: an assessment of ecological and energy indicators and effective regional management (on the example of Ukraine)
}

ABSTRACT: In this article, in accordance with the results of calculations, the authors argue that at the end of 2019, the main problems of the vast majority of regions of Ukraine are low environmental and energy efficiency and insufficient environmental protection measures.

The cluster analysis allowed us to identify common territorial groups in terms of their conditions of existence and to develop practical recommendations for priority measures of state management. The quality of clustering was checked using the silhouette measure indicator, which was used to justify the optimal number of regions, which proved to be five. Cluster I includes the Dnipropetrovsk and Zaporizhia regions. The gradual replacement of heavy industry with high-tech activities is inevitable. Cluster III includes the Volyn, Ternopil, Kherson, Khmelnytsky, Zhytomyr and Rivne regions. It is necessary to further develop the economy of the regions in compliance with

\footnotetext{
$\triangle$ Corresponding Author: Nadiia Shmygol; e-mail: nadezdash@ua.fm

1 «Zaporizhzhia Polytechnic» National University, Ukraine; ORCID iD: 0000-0001-5932-6580; e-mail: nadezdash@ua.fm

2 Classic Private University, Ukraine; ORCID iD: 0000-0003-0012-0371; e-mail: olgagaltsova67@gmail.com

3 State Scientific Institution "Institute for Modernization of the Content of Education" of the Ministry of Education and Science of Ukraine, Ukraine; ORCID iD: 0000-0003-0640-9934; e-mail: k.s.shaposhnykov@gmail.com

${ }^{4}$ L.N. Gumilyov Eurasian National University, Kazakhstan; ORCID iD: 0000-0003-4634-7061; e-mail: saule baz@mail.ru
}

2021. The Author(s). This is an open-access article distributed under the terms of the Creative Commons Attribution-ShareAlike International License (CC BY-SA 4.0, http://creativecommons.org/licenses/by-sa/4.0/), which permits use, distribution, and reproduction in any medium, provided that the Article is properly cited. 
environmental standards while taking into account the recommendations of the first cluster. Cluster IV consists of Donetsk and Luhansk regions. It is impossible to fully restore the economy of the eastern regions and its infrastructure in these conditions. Therefore, the task of public administration today is to ensure social standards of living and support the least protected segments of the population. Cluster V was built on the basis of Zakarpattia and Chernivtsi regions. The priority of state regulation should be the development of small and medium enterprises. Cluster II includes all other areas. Their economic growth must be transformed not only into the social sphere but also into technological re-equipment. The change of commodity orientation and the departure from raw material production in favor of technological is a necessary condition for maintaining the competitiveness of the economy in today's globalization. Increasing the cost of environmental measures should be a priority.

KEYWORDS: ecological and energy indicators, environmental and energy efficiency,

environmental protection measures

\section{Introduction}

In the modern period of economic management, the rate of destruction of the natural environment, problems with excessive consumption of non-renewable resources and climate change have led to the construction and development of the concept of a sustainable economy, which leads to the conclusion that economic growth has its limits. Today, the ecological aspect that forms the basis of the modern concept of social development based on the principles of a circular economy should be evaluated from different points of view. In our view, it would be interesting to assess the various components of sustainable development with different indicators, taking into account the regional aspect. Special attention should be paid to the study of the ecological and energy component.

\section{Actual scientific researches and issues analysis and the research objective in Ukraine}

Ensuring the conditions for long-term economic growth is the primary task of the macroeconomics of any country. The unstable development of the national economy in recent decades, accompanied by prolonged crisis phenomena and the slow path of reforming all spheres of life on the way to building a democratic society with a developed market economy, has drawn the constant attention of domestic scientists to this range of issues. The factors and prerequisites of economic growth in Ukraine have been studied by V. Geets, D. Ogol, S. Popovich, L. Simkiv, 
N. Skripnik, A. Bulygina, Galtsova O., Shaposhniuov K., Shmygol N. and others (Geets 2000; Ogol 2015; Popovych 2016; Simkiv 2014; Skrypnyk 2017; Shmygol et al. 2018, 2020a, 2020b, 2020c, 2021; Perevozova 2019; Belinska 2021).

The rapid development of the international economy, the uncontrolled consumption of natural resources and environmental damage have shown that linear development on a permanent basis brings significant environmental and resource problems not only for a single country but also for humanity as a whole. This is why, since the second half of the twentieth century, the developed countries of the world have begun to introduce fundamental changes in the concept of long-term economic growth based on circular development. Such a change in priorities enabled the complete rejuvinationof the environment in the course of social production through the rational use of natural resources and the introduction of a closed cycle in the consumption of material resources through the reuse of waste. The recognition of the environmental component as the main condition for further development and the need to implement the principles of a circular economy was also noted in the works of N. Gakhovich, T. Logutov, A. Poltoratsky, L. Sergienko-Berdyukov and other researchers (Gakhovich 2012; Logutova 2012; Sergienko-Berdyukova 2015). However, the scope of variation of indicators of ecological and economic efficiency in different regions of Ukraine is very large, so we need a methodology that will help identify common conditions of the existence of territorial groups and develop practical recommendations for priority measures of public administration.

\section{Scientific approaches and research methodology}

The study of the dynamics of the components of the integral indicator of the development of the Ukrainian economy often does not allow us to develop practical measures to optimize the target indicator (indicator of the development of the Ukrainian economy), since they do not contain regional data. The total number of regions in Ukraine is 25, and each of them has individual assessments of the current state that differ from others, so it is not advisable to develop practical recommendations for improving ecological and energy and economic development for each region. Instead, this study proposes to conduct a scientifically based classification of the administrative units in order to form homogeneous aggregates containing similar characteristics. The development of recommendations will then be carried out not for a single region but for the corresponding sets.

The classification of regions should not be subjective. Therefore, the impact of expert assessments in this case should be minimal. This can be achieved by using cluster analysis methods, in particular, the hierarchical agglomerative method (Pistunov 2008; Maley 2013; Gitis 2003).

The membership of each region to a certain group of similar regions is determined based on the criterion of the minimum Euclidean distance between it and the cluster centers. To do this, the values of all the indicators used for the assessment should be comparable with each other. 
This is measured on a quantitative scale in the same range of acceptable values. Otherwise, indicators with large absolute values will have a stronger impact on the calculation of distances. Therefore, normalized values of relative indicators should be used as input data.

The number of homogeneous groups and the clustering result are affected by the classification clarity parameter $\mathrm{R}$. The value of $\mathrm{R}$ is entered at the beginning of the program and is determined by an expert - its possible values range from 1 to 10 . The higher the specified clarity setting, the more sensitive the clustering method is to the distance between objects. In accordance with this, the number of formed clusters will increase.

We will choose the parameter $\mathrm{R}$ in such a way that the number of formed groups of objects is minimal, and the quality of the classification performed is within acceptable limits. The quality criterion, in this case, is the indicator of the silhouette measure.

1. Primary clustering - The purpose of this stage is to form an initial reference plan, which will be improved during the further iterative process. The criterion for combining individual regions into one group is the Euclidean distance. The distance between the $i$-th and $j$-th regions, taking into account the weight of the indicators, is calculated using the formula (1):

$$
L_{i j}=\sqrt{\sum_{k=1}^{n}\left(x_{i k}-x_{j k}\right)^{2} \cdot \alpha_{k}}
$$

where:

$L_{i j}-$ the distance between the $i$-th and $j$-th regions,

$\alpha_{k}-$ the weighting factor of the $k$-th indicator;

$n$ - the number of indicators.

The smaller the $L_{i j}$, the more similar these regions are in terms of socio-economic development, ecological and energy efficiency, ecological impact and environmental measures. The opposite statement is also true.

Primary clustering begins with the search for two regions for which $L_{i j} \rightarrow \min$. On their basis, the first cluster is formed. Subsequently, all other regions are joined to it, the distance to which from the center of gravity of the created cluster does not exceed the limit $(10-R) \cdot L_{\mathrm{min}}$. Thus, the clarity of the $\mathrm{R}$ classification directly affects the distance between the regions of each cluster and thus their total number.

After including all the objects of research in the first cluster, the next two are searched for with the minimum distance and the process continues in the same manner. The stage ends with the classification of all regions.

2. Identification of new centers of gravity and re-clustering - this stage is part of the iterative process and is performed for as long as the configuration of regions in clusters continues to change.

Based on the data of the latest classification and the arithmetic weighted average formula, new centers of gravity are calculated for each group of objects. 
The purpose of re-clustering is to identify related sets of objects around the calculated centers of gravity. In accordance with this, each region joins the nearest cluster.

By experimental analysis, the classification clarity value of $R=8.2$ was obtained, which allowed us to form five groups of regions with similar values of indicators of ecological and economic development. To check the quality of clustering, a silhouette measure was used, the value of which is calculated by formula (2).

$$
S M_{i}=\frac{L_{1 i}-L_{2 i}}{\max \left(L_{1 i} ; L_{2 i}\right)}, \quad S M=\frac{\sum_{i=1}^{m} S M_{i}}{m}
$$

where:

$S M_{i} \quad$ - the silhouette measure of the $i$-th region,

$S M$ - a generalized indicator of the silhouette measure,

$m \quad-$ the total number of regions,

$L_{1 i} \quad$ - the distance from the $i$-th region to the center of gravity of the nearest cluster;

$L_{2 i} \quad$ - the distance from the $i$-th region to the center of gravity of the cluster to which it belongs.

First, a silhouette measure is calculated for each region, and then, based on these, we find a generalizing indicator $\mathrm{SM}$, which can take values from -1 to 1 . The direction of its optimization is the maximum. In this case, the classification of objects is considered to be of higher quality, since each of them is located in close proximity to its own center of gravity and at a considerable distance from the others. The generally accepted intervals of the silhouette measure are:

$\checkmark$ if $\mathrm{SM} \geq 0.5$ - cluster analysis is able perform the classification of regions with high quality;

$\downarrow$ if $0.5>\mathrm{SM} \geq 0.2$ - an acceptable level of grouping, which enables using the results in further studies;

$\downarrow$ if $0.2>\mathrm{SM}$ - the result of the classification of regions is unsatisfactory.

According to the grouping methods of the general theory of statistics and the Sturgess formula, the optimal number of groups for a set consisting of twenty-five objects is 5-6. This statement was taken into account when implementing the clustering procedure by the agglomerative hierarchical method.

During the performed calculations, for $R=8.2$ and five formed clusters, SM is 0.43 , which corresponds to a sufficient level of quality. A further increase in the parameter $R$ did not lead to the expected growth of the silhouette measure:

$\checkmark$ at $R=8.5$, the number of clusters was 6 , and the indicator $\mathrm{SM}=0.38$;

$\checkmark$ at $R=8.6$, the number of clusters increased to $7, \mathrm{SM}=0.40$.

Taking the above into account, we selected groupings based on five clusters and four groups of indicators:

$\checkmark$ Socio-economic development (SED),

$\checkmark$ Ecological and energy development (EED), 
Environmental Pressures (EP),

$\checkmark$ Environmental Protection Measures (EPM).

As a result of scientific research and calculations, which are not given in the article due to their cumbersomeness and due to the fact that they are not the main purpose of this study, the equation of the integrated (general) indicator of national economy development (GI) was obtained, taking into account the environmental aspect:

$$
G I=0,4375 \cdot S E E+0,1875 \cdot E E D+0,1875 \cdot E P+0,1875 \cdot E P M
$$

TABLE 1. The results of calculations of the integrated (general) indicator of development of the national economy, taking into account the environmental aspect for 2019

TABELA 1. Wyniki obliczeń zintegrowanego (ogólnego) wskaźnika rozwoju gospodarki narodowej na 2019 rok z uwzględnieniem aspektu środowiskowego

\begin{tabular}{|l|c|c|c|c|c|}
\hline \multicolumn{1}{|c|}{ Region } & SED & EED & EP & EPM & GI \\
\hline Vinnytsia & 0.550 & 0.340 & 0.894 & 0.094 & 0.490 \\
\hline Volyn & 0.478 & 0.392 & 0.934 & 0.150 & 0.486 \\
\hline Dnepropetrovsk & 0.598 & 0.084 & 0.641 & 0.217 & 0.438 \\
\hline Donetsk & 0.503 & 0.026 & 0.697 & 0.233 & 0.399 \\
\hline Zhytomyr & 0.510 & 0.311 & 0.912 & 0.135 & 0.478 \\
\hline Zakarpattia & 0.444 & 0.477 & 0.975 & 0.067 & 0.479 \\
\hline Zaporizhia & 0.544 & 0.042 & 0.776 & 0.383 & 0.463 \\
\hline Ivano-Frankivsk & 0.513 & 0.272 & 0.875 & 0.205 & 0.478 \\
\hline Kyiv & 0.565 & 0.317 & 0.883 & 0.414 & 0.550 \\
\hline Kirovograd & 0.516 & 0.186 & 0.886 & 0.114 & 0.448 \\
\hline Luhansk & 0.450 & 0.075 & 0.884 & 0.181 & 0.411 \\
\hline Lviv & 0.518 & 0.244 & 0.906 & 0.111 & 0.463 \\
\hline Mykolayivska & 0.532 & 0.087 & 0.913 & 0.115 & 0.442 \\
\hline Odessa & 0.524 & 0.198 & 0.916 & 0.033 & 0.445 \\
\hline Poltava & 0.558 & 0.351 & 0.796 & 0.111 & 0.480 \\
\hline Rivne & 0.498 & 0.209 & 0.926 & 0.160 & 0.461 \\
\hline Sumy & 0.515 & 0.193 & 0.764 & 0.119 & 0.427 \\
\hline Ternopil & 0.474 & 0.230 & 0.893 & 0.150 & 0.446 \\
\hline Kharkiv & 0.498 & 0.165 & 0.865 & 0.082 & 0.427 \\
\hline Kherson & 0.462 & 0.256 & 0.916 & 0.092 & 0.439 \\
\hline Khmelnytsky & 0.488 & 0.298 & 0.886 & 0.295 & 0.491 \\
\hline Cherkasy & 0.505 & 0.231 & 0.887 & 0.119 & 0.453 \\
\hline Chernivtsi & 0.442 & 0.505 & 0.950 & 0.134 & 0.491 \\
\hline Chernihiv & 0.486 & 0.236 & 0.886 & 0.086 & 0.439 \\
\hline
\end{tabular}

Source: own study. 
During the study, certain features were observed:

$\checkmark$ With a decrease of the center of gravity according to the SED indicator, the level of ecological and energy efficiency and the environmental pressures of the regions tend to improve. In other words, the worst level of economic development corresponds to the best state of the environment and vice versa. The exceptions are the regions of Cluster IV, where low levels of SED, EED and EP are interconnected.

\ The level of environmental protection measures at enterprises in all regions remains consistently low and does not depend on the state of other indicators. The exceptions are regions of Cluster I where the ecological and energy situation is the worst.

\section{Practical recommendations for the development of regions}

Taking into account these interdependencies, it is possible to form practical recommendations for the development of the regions of each cluster.

\subsection{Analysis of the first cluster}

The first set included Dnipropetrovsk and Zaporizhia regions (see Table 2).

TABLE 2. First cluster: regions with the highest level of SED

TABELA 2. Klaster pierwszy: obwody o najwyższym poziomie społeczno-gospodarczym

\begin{tabular}{|l|c|c|c|c|c|}
\hline \multicolumn{1}{|c|}{ Region } & SED & EED & EP & EPM & GI \\
\hline Dnepropetrovsk & 0.9698 & 0.1312 & 0.4402 & 0.2175 & 0.5722 \\
\hline Zaporizhia & 0.8291 & 0.1031 & 0.6662 & 0.3831 & 0.5788 \\
\hline Cluster center & 0.8994 & 0.1172 & 0.5532 & 0.3003 & - \\
\hline
\end{tabular}

Source: own study.

In comparison with other regions, in 2019 these regions had a high level of socio-economic development and one of the worst environmental conditions, which is negative. Therefore, recommendations for their further development will be in the context of ensuring the ecological and energy security of the regions. This situation is due to the constant dominance of heavy industry in the field of production. Extraction and primary processing of natural resources and minerals have low added value compared to the production of high-tech products; however, they pose a significant threat to the natural environment. Such a situation can be radically changed only by restructuring of the economy of these regions (Pistunov 2008; Maley 2013; Gitis 2003). 
Of the most urgent environmental problems, the following should be noted:

1. The largest volumes of waste generation in Ukraine are in the Dnipropetrovsk region and amount to 79.0 thousand tha. It is known from economic geography that about $50 \%$ of all mineral resources in Ukraine are located in the territory of the Dnipropetrovsk region. Thus, the Nikopol manganese ore basin is the largest in the world. Furthermore, the Krivoy Rog iron-ore basin ranks first in Ukraine in terms of reserves. Thus, the main source of waste generation is the extractive industry. This led to the fact that as of the end of 2019, over 10 billion tons were accumulated here, or $69.4 \%$ of all waste in Ukraine.

2. In the Zaporizhia region, 7653 thousand tons were stored, or $62.2 \%$ of all hazardous waste in Ukraine. There are 2,815 thousand tons of waste of hazard classes I-III per 1 ha, with the national average level of 0.2 tons/ ha.

3. Production enterprises in the regions of this cluster are one of the largest air polluters, with pollutants including carbon dioxide emissions.

The effective use of natural resources requires significant expenditure on environmental protection. First of all, it is unacceptable to save money on treatment facilities and the purification of atmospheric emissions. Secondly, more complete ore processing and waste disposal is a priority of the circular economy, on the basis of which, the European Union operates (Kartikeyan et al 2013; Sasirekha and Baby 2013; Kuchaki et al. 2012). However, in practice, the implementation of an appropriate set of measures would lead to a loss of competitiveness of Ukrainian enterprises in the markets due to rising prices for products. Therefore, the gradual replacement of heavy industry with high-tech activities is inevitable. The conditions for this should be:

$\checkmark$ the creation of a competitive environment and free entry into the market, effective activity of the Antimonopoly Committee and the prevention of blocking by large business owners of small and medium business initiatives;

$\checkmark$ the openness of markets for external investment through state deregulation of these processes;

$\checkmark$ strict compliance with the norms of domestic environmental legislation and acceleration of the processes of its adaptation to the standards of the European Union (Kartikeyan et al. 2013; Sasirekha and Baby 2013; Kuchaki et al. 2012).

\subsection{Fifth cluster analysis}

The fifth cluster is the complete opposite of the previous one. It includes the Zakarpattia and Chernivtsi regions (see Table 3). Their special difference is the lowest generalized level of socio-economic development, combined with the best indicators of rational nature management and environmental pollution. The reason for this is the industrial orientation towards processing economic activities with a relatively low level of pollution.

The main problems of these regions in 2019 included:

1. Low level of gross regional product per capita, which was $42-44 \%$ of the national average. At the same time, the annual income per capita was $65-70 \%$ of the average in Ukraine. Thus, in 
TABLE 3. Fifth cluster: regions with the lowest level of SED

TABELA 3. Klaster piąty: obwody o najniższym poziome społeczno-gospodarczym

\begin{tabular}{|l|c|c|c|c|c|}
\hline \multicolumn{1}{|c|}{ Region } & SED & EED & EP & EPM & GI \\
\hline Zakarpattia & 0.5449 & 0.8522 & 0.9346 & 0.0675 & 0.5861 \\
\hline Chernivtsi & 0.5139 & 0.8120 & 0.8850 & 0.1338 & 0.5681 \\
\hline Center of gravity & 0.5294 & 0.8321 & 0.9098 & 0.1006 & - \\
\hline
\end{tabular}

Source: own study.

2019 there was a situation when the total income of the population exceeded the corresponding volumes of GRP (gross regional product is a measure of size or net wealth generated by the local economy, is simply GDP for the region of study):

$\checkmark$ In the Zakarpattia region, revenues amounted to UAH 77,568 million, which is 1.4 times more than GRP.

$\downarrow$ In the Chernivtsi region, revenues amounted to UAH 57,755 million and 1.6 times more than GRP.

Thus, both regions are subsidized, creating an additional burden on the state budget due to inter-budget transfers. According to the current legislation, equalization subsidies must provide a single level of social security throughout Ukraine, under certain items of expenditure.

2. The excess of expenditures of the population over their annual incomes in these regions is also the maximum in Ukraine: in Zakarpattia the excess was $14.1 \%$, and in Chernivtsi, it was $24.3 \%$. In fact, the low level of economic development contributes to labor migration.

Given the above, the main priority of state regulation should be economic development through small and medium enterprises.

\subsection{Analysis of the fourth cluster}

The fourth cluster differs from others by objective factors that significantly affected its current state, starting in 2014, this includes Donetsk and Luhansk regions (see Table 4).

TABLE 4. Fourth cluster: regions with the lowest level of GI

TABELA 4. Klaster czwarty: obwody o najniższym poziomie ogólnego wskaźnika rozwoju gospodarki

\begin{tabular}{|l|c|c|c|c|c|}
\hline \multicolumn{1}{|c|}{ Region } & SED & EED & EP & EPM & GI \\
\hline Donetsk & 0.6324 & 0.0461 & 0.4377 & 0.2329 & 0.4111 \\
\hline Luhansk & 0.5314 & 0.1623 & 0.8198 & 0.1811 & 0.4506 \\
\hline Center of gravity & 0.5819 & 0.1042 & 0.6287 & 0.2070 & - \\
\hline
\end{tabular}

Source: own study. 
The economy in eastern Ukraine has been undermined by the temporary occupation. At the same time, its sectoral focus on heavy industry has caused a difficult environmental situation. Taking into account all components, the integrated indicator of GI in 2019 was the lowest of all regions. The main problems of Donetsk and Luhansk regions, according to the analysis, include:

1. The low level of GRP per capita in the Donetsk region was $52 \%$ of the national average, and in the Luhansk region, it was $20 \%$. Similarly, income per capita in the Donetsk region was $52 \%$, and in the Luhansk region, it was $36 \%$ when compared to other regions.

2. Almost all indicators of ecological and energy efficiency in 2019 were among the worst values in Ukraine. In addition, in terms of the environmental pressures, the Donetsk region is one of the worst.

The complete recovery of the economy of the eastern regions and its infrastructure in these conditions is impossible. Therefore, the task of public administration today is to ensure social standards of living and support for the least protected segments of the population. In the future, the restoration of these regions is possible only through the development of state support programs and investment development strategies.

Thus, we have considered the extreme cases of the state of the national economy in 2019 according to the components of the integral indicator. On the one hand, we had a relatively high level of socio-economic growth combined with excessively harmful heavy industry. On the other hand, the environmental situation is at an acceptable level, the price of which is a low level of gross domestic product per capita.

The centers of gravity of the second and third clusters are intermediate points between the extreme cases. In relation to Dnipropetrovsk and Zaporizhia oblasts, the indicators of SED are starting to decrease, and the rational use of nature management is growing.

\subsection{Analysis of the second cluster}

The second cluster has the most regions of all the others. Its composition and estimates of the integral indicators are given in Table 5.

Given the numerical composition of this cluster (Table 5), it can be argued that it identifies the main trends in the national economy and forms the average level of evaluation indicators. According to 2019 data, about $43 \%$ of the country's GDP was produced in these regions. Therefore, the development strategy of these areas should be comprehensive and take into account all aspects of life.

Despite the fact that the values of the group indicators for which clustering was performed are relatively close to the center of gravity (Table 5), some regions have significant problems with individual indicators of economic development and its impact on the environment. Solving these problems should be a priority for state regulation, so we will consider them in more detail.

1. Although socio-economic development is a strength of this cluster, the volume of gross regional product per capita in the Ivano-Frankivsk region in 2019 was only $72.6 \%$ of the national 
TABLE 5. Second cluster: regions with balanced development

TABELA 5. Klaster drugi: obwody o zrównoważonym rozwoju

\begin{tabular}{|l|c|c|c|c|c|}
\hline \multicolumn{1}{|c|}{ Region } & SED & EED & EP & EPM & GI \\
\hline Vinnytsia & 0.8034 & 0.5193 & 0.8102 & 0.0935 & 0.6183 \\
\hline Ivano-Frankivsk & 0.7117 & 0.4079 & 0.7367 & 0.2050 & 0.5644 \\
\hline Kyiv & 0.8326 & 0.6109 & 0.7762 & 0.4140 & 0.7019 \\
\hline Kirovograd & 0.7263 & 0.3702 & 0.8032 & 0.1143 & 0.5592 \\
\hline Lviv & 0.7258 & 0.4666 & 0.8118 & 0.1112 & 0.5781 \\
\hline Mykolayivska & 0.7765 & 0.2579 & 0.8558 & 0.1153 & 0.5702 \\
\hline Odessa & 0.7402 & 0.5171 & 0.8612 & 0.0332 & 0.5885 \\
\hline Poltava & 0.8760 & 0.5119 & 0.5604 & 0.1106 & 0.6051 \\
\hline Sumy & 0.7506 & 0.3411 & 0.6008 & 0.1195 & 0.5274 \\
\hline Kharkiv & 0.6926 & 0.3418 & 0.7402 & 0.0822 & 0.5213 \\
\hline Cherkasy & 0.6975 & 0.4739 & 0.7987 & 0.1189 & 0.5661 \\
\hline Chernihiv & 0.6688 & 0.4752 & 0.8265 & 0.0857 & 0.5527 \\
\hline Center of gravity & 0.7664 & 0.4656 & 0.7330 & 0.1256 & - \\
\hline
\end{tabular}

Source: own study.

average, in Chernihiv - it was $73.3 \%$, in Sumy it was $75.7 \%$ and in Lviv it was $82.1 \%$. The largest excess of annual expenditures of the population over incomes was observed in economically developed regions, such as: Kharkiv $(+28.6 \%)$, Kyiv $(+22.2 \%)$ and Odessa $(+15.6 \%)$ regions. On the one hand, this indicator is evidence of low income, and on the other, evidence of the tendency to increased demand.

2. According to the level of ecological and energy efficiency, Nikolaev, Sumy, Kharkiv and Kirovograd regions had low generalizing indicators, although others also had problems. First of all, the high volume of atmospheric emissions of pollutants and carbon dioxide relative to the gross regional product in Ivano-Frankivsk and Vinnytsia regions should be noted. A high level of waste generation relative to GRP took place in the Kirovograd, Mykolaiv, Poltava, Sumy and Kharkiv regions. Additionally, in the Nikolaev region, one of the lowest volumes of harvesting of forest products for the area of forest felling was observed in the country, which amounted to $16.4 \mathrm{~m}^{3} / \mathrm{ha}$.

3. In terms of the environmental pressures of the regions, the worst situation is in the Poltava region, where the volume of waste generation per area in 2019 was 33.9 tons/ha, which is the worst indicator in the entire cluster. The total amount of accumulated waste on its territory was 847 tons/ ha and was second only to Dnipropetrovsk region, where this indicator was 3349 tons $/$ ha.

4. The volume of environmental protection measures in the enterprises of the region is not enough. The main reason for this is a lack of funding for environmental protection costs. Thus, in the Vinnytsia, Kirovohrad, Lviv, Mykolaiv, Odessa, Sumy, Cherkasy and Chernihiv regions, the corresponding expenditures in 2019 did not exceed $0.1 \%$ of the gross regional product. The 
leader in this indicator, not only within the considered cluster but also in Ukraine as a whole, is the Kyiv region with a cost level of $3.3 \%$.

Complete waste disposal is one of the main tasks of the circular economy, which has been systematically implemented in EU countries since the end of the twentieth century. The Association Agreement with the European Union provides for the implementation of the Waste Directive 2008/98. While the average share of recycled waste in Ukraine in the total volume formed in 2019 was $24.5 \%$, in certain areas of this cluster it was much lower $-0.4 \%$ in the Odessa region, $0.7 \%$ in Kiev, $2.6 \%$ in Mykolaiv, $3.1 \%$ in Poltava, $4.5 \%$ in Kirovograd. However, there is also a regional leader, which is the Cherkasy region, where this indicator was $55.4 \%$. The irresponsible attitude to the use of water resources is characterized by the lack of sufficient treatment facilities in some regions. In Ukraine as a whole, sewage treatment plants cover $99.5 \%$ of the total volume of wastewater disposal. In the Kiev region, this indicator was $28.5 \%$, in Mykolaiv it was $71.8 \%$ and in Cherkasy it was $73.1 \%$. The greatest water savings due to reuse, relative to the volume of intake, were in Ivano-Frankivsk (19.9 times), Mykolaiv (14.4 times) and Vinnytsia (13.0 times). In contrast, savings were almost absent in the Odessa (0.1) and Kirovograd (0.2) regions.

Thus, we have a situation where, according to the relatively close values of group indicators, there are certain regional problems related to the rational use of nature. The reason for this state include the specifics of economic activity and industrial development. Global improvement should include the following measures:

$\checkmark$ Economic growth should be transformed not only into the social sphere but also into technological re-equipment. Changing the commodity orientation and moving away from the production of raw materials in favor of technological production is a necessary condition for maintaining the competitiveness of the economy in the modern conditions of globalization.

$\checkmark$ Attracting foreign investment should be accompanied by a departure from the monopolistic or oligopolistic division of the domestic market.

$\checkmark$ It is necessary to radically change the consumer attitude to natural resources and the environment. The priority should be to increase the costs of environmental protection measures.

\subsection{Analysis of the third cluster}

The third cluster includes the Volyn, Ternopil, Kherson, Khmelnitsky, Zhytomyr and Rivne regions (see Table 6).

Unlike in the previous cluster, the above regions are inferior to the $S E D$ indicator; however, have much better positions in EED and EP, which is positive.

The main economic problem of the region of this cluster was the low level of GRP per capita. In some regions, this figure was as follows: in the Ternopil region, it was $53.3 \%$ of the average level in Ukraine; $57,1 \%$ in Volyn; $61.9 \%$ in Kherson, $62.7 \%$ in Rivne. Other shortcomings of 
TABLE 6. Third cluster: regions with balanced development

TABELA 6. Klaster trzeci: obwody o zrównoważonym rozwoju

\begin{tabular}{|l|c|c|c|c|c|}
\hline \multicolumn{1}{|c|}{ Region } & SED & EED & EP & EPM & GI \\
\hline Volyn & 0,6284 & 0,7264 & 0,8697 & 0,1502 & 0,6024 \\
\hline Ternopil & 0,6219 & 0,4481 & 0,8208 & 0,1505 & 0,5382 \\
\hline Kherson & 0,5958 & 0,5341 & 0,8087 & 0,0915 & 0,5296 \\
\hline Khmelnytsky & 0,6563 & 0,5589 & 0,8044 & 0,2953 & 0,5981 \\
\hline Zhytomyr & 0,7000 & 0,7220 & 0,8270 & 0,1352 & 0,6220 \\
\hline Rivne & 0,6865 & 0,5635 & 0,8439 & 0,1605 & 0,5943 \\
\hline Center of gravity & 0,6482 & 0,5922 & 0,8291 & 0,1639 & - \\
\hline
\end{tabular}

Source: own study.

socio-economic development were also derived from this data. In contrast to the regions of the second cluster, the volumes of industrial emissions and environmental pollution are much smaller here. Ecological problems also exist here; however, they are much less. For example, in the Kherson region, the ratio of GRP to the volume of hazardous waste is 2.5 times lower than the average in the Ukraine. Therefore, the main recommendation in this case is the development of the economy of the regions in compliance with environmental standards.

\section{Summary results of comparison}

Summarizing the results of calculations, it can be argued that at the end of 2019, the main problems of the vast majority of regions of Ukraine were low environmental and energy efficiency and insufficient environmental protection measures. However, we should not forget that the strategic development of the national economy should be based on a diversified approach, taking into account the specifics of each region.

The cluster analysis allowed us to identify common territorial groups in terms of their conditions of existence and enabled us to develop practical recommendations for priority measures of state management. The quality of clustering was checked using the silhouette measure indicator. This was used to justify the optimal number of regions, which was five.

As a result of a comparative analysis of the components of the integrated indicator of national economic development, it was found that with the decrease of the center of gravity according to the $S E D$, the level of ecological and energy efficiency and the environmental pressures of regions tend to improve. Thus, the best level of economic development corresponds to a better state of the environment. Exceptions are regions of Cluster IV, where low levels of SED, EED and EP are related to each other: 
$\checkmark$ Cluster I includes the Dnipropetrovsk and Zaporizhia regions. The gradual replacement of heavy industry with high-tech activities is inevitable. The conditions for this should be: the creation of a competitive environment and free entry to the market; effective activity of the antimonopoly committee and preventing the blocking of small and medium-sized business initiatives by large business owners; the openness of markets for external investment through state deregulation of these processes; compliance with the norms of domestic environmental legislation and acceleration of the processes of its adaptation to EU regulations.

\ Cluster III includes the Volyn, Ternopil, Kherson, Khmelnytsky, Zhytomyr and Rivne regions. It is necessary to further develop the economy of the regions in compliance with environmental standards and take into account the recommendations of the first cluster.

$\checkmark$ Cluster IV consists of the Donetsk and Luhansk regions. It is impossible to fully restore the economy of the eastern regions and its infrastructure in these conditions. Therefore, the task of public administration today is to ensure social standards of living and support the least protected segments of the population. In the future, the restoration of these regions is possible only through the development of state support programs and investment development strategies.

- Cluster V was built on the basis of the Zakarpattia and Chernivtsi regions. The priority of state regulation should be the development of small and medium enterprises.

$\checkmark$ Cluster II included all other areas. Their economic growth must be transformed not only into the social sphere but also into technological re-equipment. Change of commodity orientation and departure from raw material production in favor of technological production is a necessary condition for maintaining the competitiveness of the economy in today's globalization. Attracting foreign investment should be accompanied by a departure from the monopolistic or oligopolistic division of the domestic market; this is necessary to radically change the consumer attitude to natural resources and the environment. Increasing the cost of environmental measures should be a priority.

Summing up the above, we can say that the advantages of this methodology lie in the fact that we proposed to conduct a scientifically based classification of administrative units in order to form homogeneous aggregates with similar characteristics. The development of recommendations can then be carried out not for one region but for the corresponding sets of economic restructuring, which will speed up the monitoring process and should facilitate the transition to more efficient and environmentally friendly activities.

\title{
The list of abbreviations
}

\author{
SED - Socio-economic Development, \\ EED - Ecological and Energy Development, \\ EP - Environmental Pressures, \\ EPM - Environmental Protection Measures,
}


GI - General Indicator of the Development of the Ukrainian economy,

SM - Generalized Indicator of the Silhouette Measure,

GRP - Gross Regional Product.

\section{References}

Belinska et al. 2021 - Belinska, Y., Matvejciuk, L., Shmygol, N., Pulina, T. and Antoniuk, D. 2021. EU agricultural policy and its role in smoothing the sustainable development of the EU's agricultural areas. IOP Conference Series: Earth and Environmental Science 628(1), 012030, DOI: 10.1088/1755$1315 / 628 / 1 / 012030$.

GAKHOVICH, N.G. 2012. Ecologization of industrial production as a necessary condition for overcoming disproportion. [In:] World economic disproportion: features, tendencies, influence on the economy of Ukraine: scientific report, ed. Corresponding Member NAS of Ukraine L.V. Shinkaruk; NAS of Ukraine, In-t. Of Economics and predicted. NAS of Ukraine, pp. 94-98.

GeETs, V.M. 2000. Instability and economic growth. V.M. Gay. K. In-t. Economics. forecast., 344 p.

Gitis, L.H. 2003. Statistical classification and cluster analysis. L.H. Gitis. M., 157 p.

Kartikeyan et al. 2013 - Kartikeyan, T., Ragavan, R. and Vembandasamy, K. 2013. Hierarchical K-Means Clustering Algorithm for an E-Care of Diabetes Mellitus.

KuchaKi et al. 2012 - KuCHAKI, R.M., AsGHARI, V.Z. and EmAmi, C.N. 2012. A Survey of Hierarchical clustering algorithms. The Journal of Mathematics and Computer Science 5(3), pp. 229-240.

Logutova, T.G. 2012. The problem of resource provision in the world economy. T.G. Logutova, O.V. Poltoratska, Theoretical and practical aspects of economics and intellectual property: a collection of scientific papers: in 2 issues; PDTU - Mariupol, Vip. 1., T. 1, pp. 205-211.

MALEY, O.V. 2013. On the issue of development of the modern waste management system in Ukraine. O.B. Malei, A.O. Klyuchka, Ecological management in the general management system: collection of abstracts of the Thirteenth annual all-Ukrainian scientific conference, Sumy, April 17-18, 2013 / Resp. O.M. Telizhenko. Sumy: Sumy State University, pp. 91-94.

OGOL, D.O. 2015. Economic growth: essence, quality and sustainability. Actual problems of economy 2, pp. 67-72. [Online] http://nbuv.gov.ua/UJRN/ape_2015_2_11 [Accessed: 2021-09-02].

Perevozova et al. 2019 - Perevozova, I., Shmygol, N., Tereshchenko, D., Kandahura, K. and KaterNA, O. 2019. Introduction of creative economy in international relations: Aspects of development security. Journal of Security and Sustainability Issues 9(1), pp. 139-154, DOI: 10.9770/jssi.2019.9.1(11).

Pistunov, I.M. 2008. Cluster analysis in economics: textbook. way. I.M. Pistunov, O.P. Antonyuk, I.Y. Turchaninov. Dnepropetrovsk: Nat. min. University, 84 p.

Popovych, Z. 2016. Economic growth and prospects for innovative development. Economy of Ukraine 12, pp. 41-48.

Sasirekha, K. and Baby, P. 2013. Agglomerative Hierarchical Clustering Algorithm-A Review. Vol. 3.

SERGIENKo-Berdyukova, L.V. 2015. Prerequisites for the formation and implementation of the concept of circular economy. Problems of theory and methodology of accounting, controlan analysis 3(33), pp. 327-350.

Simkiv, L.E. 2014. Qualitative economic growth in Ukraine, its assessment and ways of providing. Innovative economy 2, pp. 21-25. [Online] http://nbuv.gov.ua/UJRN/inek_2014_2_4 [Accessed: 202109-02].

Shmygol et al. 2018 - Shmygol, N., Galtsova, O. and Varlamova, I. 2018. Developing a methodology to assess the environmental and economic performance index based on international research to solve the 
economic and environmental problems of Ukraine. Baltic Journal of Economic 4, pp. 366-375, DOI: 10.30525/2256-0742/2018-4-4-366-374.

Shmygol et al. 2020a - Shmygol, N., Cherniavska, O., Pulina, T. and Zavgorodniy, R. 2020a. Economic assessment of the implementation of the resource-efficient strategy in the oil and gas sector of the economy on the basis of distribution of trade margins between extracting and processing enterprises Polityka Energetyczna - Energy Policy Journal 23(3), pp. 135-146, DOI: 10.33223/epj/126998.

Shmygol et al. 2020b - Shmygol, N., Łuczka, W., Trokhymets, O., Pawliszczy, D. and Zavgorodniy, R. 2020b. Model of diagnostics of resource efficiency in oil and gas sector of economy of Ukraine. E3S Web of Conferences 166, DOI: 10.1051/e3sconf/202016613005.

Shmygol et al. 2021 - Shmygol, N., Solovyov, O., Kasianok, M., Cherniavska, O. and Pawliszczy, D. Model of sectoral competitiveness index by environmental component. IOP Conference Series: Earth and Environmental Science 628(1), DOI: 10.1088/1755-1315/628/1/012023.

SKRYPNYK, N.E. 2017. Factors and preconditions of economic growth in Ukraine. N.Y. Skripnik, A.V. Bulygina, Eastern Europe: Economics, Business and Management 6, pp. 11-15.

\section{Polityka zarządzania środowiskowego: ocena wskaźników ekologicznych i energetycznych oraz efektywnego zarządzania regionalnego (na przykładzie Ukrainy)}

\section{Streszczenie}

W artykule, zgodnie z wynikami obliczeń, autorzy przekonują, że na koniec 2019 roku głównymi problemami zdecydowanej większości regionów Ukrainy są niska efektywność środowiskowa i energetyczna oraz niewystarczające środki ochrony środowiska. Analiza skupień pozwoliła na zidentyfikowanie grup terytorialnych mających wspólne warunki funkcjonowania oraz wypracowanie dla nich praktycznych rekomendacji ze względu na priorytetowe działania państwa.

Jakość skupienia sprawdzono za pomocą współczynnika zarysu (ang. silhouette), który posłużył do uzasadnienia optymalnej liczby regionów; wynik wskazał na pięć skupień (klastrów).

Klaster I obejmuje obwody: dniepropietrowski i zaporoski. Stopniowe zastępowanie przemysłu ciężkiego działalnością high-tech jest nieuniknione.

Klaster III obejmuje obwody: wołyński, tarnopolski, chersoński, chmielnicki, żytomierski i równieński. Niezbędny jest dalszy rozwój gospodarki regionów zgodnie z normami środowiskowymi z uwzględnieniem rekomendacji pierwszego klastra.

Klaster IV składa się z obwodów donieckiego i ługańskiego. W obecnych warunkach niemożliwe jest pełne odbudowanie gospodarki regionów wschodnich i ich infrastruktury. Dlatego zadaniem administracji publicznej jest dziś zapewnienie socjalnych standardów życia i wspieranie najmniej chronionych grup ludności. 
Klaster V został zbudowany na bazie obwodów zakarpackiego i czerniowieckiego. Priorytetem regulacji państwowych powinien być rozwój małych i średnich przedsiębiorstw.

Klaster II obejmuje wszystkie pozostałe obwody. Dla ich wzrostu gospodarczego niezbędna jest transformacja nie tylko w sferze społecznej, ale także zmiana technologiczne. Zmiana orientacji towarowej i odejście od produkcji surowcowej na rzecz technologicznej jest warunkiem koniecznym utrzymania konkurencyjności gospodarki w dzisiejszej globalizacji. Zwiększenie działań prośrodowiskowych powinno być priorytetem.

SŁOWA KLUCZOWE: wskaźniki ekologiczne i energetyczne, efektywność środowiskowa i energetyczna, środki ochrony środowiska 
